\title{
Könyvszemle
}

SIPOS JÚLIA GONDOZÁSÁBAN

\section{SPENGLER UTÁN}

Európa alkonya? Ha ezt szegény Oswald Spengler megérhette volna! Pontosan száz évvel híres müve - pontosabban: híres müve első kötetének - megjelenése után, kérdése, íme, még mindig, vagy inkább, már megint aktuálisnak látszik. Gyurgyák János nyilvánvalóan játszik velünk, olvasóival. Nagy levegőt vesz, saját könyvének olyan címet ad, amelyik rájátszik a régi híres mü címére. A Nyugat alkonya után egy évszázaddal, lám, elérkeztünk Európa alkonyához?

Ráadásul, bevezetésként ezt a megfigyelésünket is azonnal el kell árulnunk: mintha többről is szó lenne. A teoretikus spekuláció és a politikai értekezés müfaji keveredéséről tudniillik. A régi híres mü, A Nyugat alkonya, ugye, egyszerre volt bölcseleti világregény és politikai vitairat. Mint világregény hatalmas víziót nyújtott az emberi történelem egészéről. Elképesztően gazdag történelmi anyaga nagy ívü - ciklikus történetfilozófiára, a kultúra-civilizáció ellentétére, illetve történelmi predikcióra épülő - koncepcióba illeszkedett. Mint politikai vitairat a német első világháborús összeomlás megrázkódtató élményére fogalmazott választ. Telibe találva a korhangulatot, egyszerre fejezte ki a kétségbeesést és nyújtott metafizikai vigaszt: valóban végünk van, ám nem csak nekünk, németeknek, az egész, civilizációvá silányodott nyugati kultúránknak. Az Európa alkonya?, hasonlóképp, egyszerre eszmetörténeti összefoglaló és értelmiségi számvetés. Mint eszmetörténeti összefoglaló, az Európa-kérdés különféle metszeteit mutatja föl, szenvtelenül és tudományosan. Mint értelmiségi számvetés, az európai értékek mellett foglal állást, szenvedélyesen és egzisztenciális érintettséggel.

Gyurgyák az előszóban beszámol a motivációkról, amelyek müve megírására indították; ezek között harmadikként említi azt, ami a mi olvasatunkban inkább az élre kívánkoznék: hogy tudniillik a „meneküléskényszer” vette rá a könyvírásra. A hazai politikai rendszer, az ,illiberális demokrácia”, ez az „,autokráciába hajló uralom” a „magyar ügyet”, úgymond, „hosszú időre ismét perspektívátlanná" tette ugyanis. Nem akárki nyilvánítja ki ezt ráadásul: a jelenlegi berendezkedés kiépítőinek egykori személyes jó barátja, a kormányzatot adó politikai erő valaha volt fontos ideológusa. Olyan valaki, aki a nyolcvankilences csendes félforradalomtól, elsősorban a maga nemzedékétől várta, hogy „,Kompországot” végre révbe kormányozza, ahol a nemzet európai értékek iránti elkötelezettsége 
többé nem kérdőjelezhető majd meg. Mit mondjunk - ő is elárulja -, nemzedékével és nemzetével együtt csalódnia kellett. Ezért van, hogy az olvasó nem tudja nem észrevenni: nem egyszerüen hủvös szaktudományos értekezést tart a kezében; a szenvtelenség hüvös felszíne alól mindegyre fölsejlik a szenvedély heve. Gyurgyák nem egyszerủen beszámol valamiről: állást foglal valami mellett és valami ellen. Az európai uniós értékek mellett és az európai uniós értékek cinikus - illiberális-autokratikus - kijátszása ellen.

Az állásfoglalást ráadásul megkönnyíti, hogy az Európa-perspektívákat nyitottnak látja. És ezzel véget is érnek a Spengler-analógiák. A Nyugat alkonya cím után nem szerepelt kérdőjel. Spengler szigorúan determinisztikus könyvet készített. A kultúrák, ezek a kvázi-élőlények, születnek, fölnőnek, megöregszenek, majd meghalnak. Ahogy minden kultúra, az európai kultúra is civilizációvá szárad, hogy szükségképp elpusztuljon. Az Európa alkonya? cím viszont így szerepel, kérdőjellel. Gyurgyák nem lát determinációkat, nem dolgozik organicista analógiákkal, nem jövendöl halált, nem vizionál pusztulást. Az Európa-projekt, mondja, nyitott. Különleges intézményrendszere, az unió tényleg válságban van ugyan, de története éppenséggel azt igazolja, hogy különleges képessége alakult ki a válságainak kezelésére.

Szóval, mit olvasunk tehát?

Olyan könyvet, amely valahol a tanulmánygyüjtemény és a monográfia között foglal helyet. Tanulmánygyüjteménynél több, a mi, kontinentális fogalmaink szerinti monográfiánál ellenben kevesebb. Leginkább angolszász minták szerint szerzett monográfiának látszik. Tematikusan összefüzött és egymásra reflektáló tanulmányok gyüjteménye tehát, amely azonban nem dolgozza föl a teljesség igényével a maga tárgyát; releváns szempontok szerint válogatott tanulmányfüzére mégis összefoglaló képet rajzol tárgyalt problémájáról.

Tanulmányai - összesen hat van belölük, a kötet hat fejezetét képezve - a következő sorrendben követik egymást. Az első az „európai identitás” nyomába ered; a második a „spengleri kérdést” - az európaisággal foglalkozó legkiemelkedőbb történetfilozófiai teóriákat - veszi számba; a harmadik Európa „őskatasztrófájának" - az első világháborúnak - a következményeit elemzi; a negyedik az Európai Unió dilemmáit vizsgálja meg; az ötödik a németek - mint a legmeghatározóbb uniós nemzet -, a hatodik pedig az oroszok - mint a legfontosabb unión kívüli nemzet - és Európa viszonyát járja körül. A fölsorolásból azonnal kitűnik: a megközelítésmód figyelemre méltóan sokszínủ. Szerepel itt szigorúbban történeti-politikatörténeti-gazdaságtörténeti irányú, politológiai-politikatudományi szempontú meg filozófiai-történetfilozófiai érdekű fejezet. A különféle megközelítéseket ugyanakkor egységbe foglalja a szerző határozott eszmetörténeti érdeklődése.

Gyurgyák ugyanis, tudni kell róla, eredendően eszmetörténész. Eddigi meghatározó könyveit a magyar gondolkodástörténet különféle kérdéseinek 
szentelte, markánsan eszmetörténeti megközelítéssel. A magyar antiszemitizmus történetéről írott nagymonográfiája a történeti keretek fölvázolása után a zsidókérdésről megfogalmazott álláspontokat ismertette, a zsidóságon belüli ortodox-neológ nézetektől a jobboldali radikális-antiszemita felfogásokig, a liberális-konzervatív véleményektől a népi beállításokig, a polgári radikális megnyilatkozásoktól a szociáldemokrata elgondolásokig. A magyar nemzeteszme alakulását nagyelbeszélésbe foglaló munkája a nacionalizmus fejlődéstörténetének fonalára füzve voltaképp a 19. és a 20. század magyar eszmetörténetének egészét megjelenítette, aprólékosan elmesélve, mit gondolnak a nemzetről az egyes ideológiai irányzatok képviselöi, a klasszikus szabadelvủektől a polgári radikálisokon-urbánusokon, a fajvédőkön-rasszistákon és a konzervatívokon keresztül a népiekig meg a szocialistákig-kommunistákig. A magyar fajvédelem képviselőit számba vevő földolgozása pedig a rasszista gondolat képviselöi fölött tartott szemlét, eszmetörténeti portrék sorozatába füzve a gondolat megvalósítóinak egyes típusait, a prófétától elindulva, a „sajtóapostolon", a tudóson, a politikuson és a publicistán keresztül megérkezve egészen a mozgalmárig.

Itt, ebben a kötetben is voltaképp azt teszi, amit a legjobban szeret, és amihez a legjobban ért. Előveszi az egyes tárgyalt problémák különféle reprezentatív megfogalmazóit, megszólaltatja, értékeli és összehasonlítja őket. Az európai identitásnak utánagondoló fejezet - Európát földrajzi fogalomként meghatározó viták rövid ismertetése után - a történeti megközelítéseket veszi sorra: azoknak a történészeknek-politikai gondolkodóknak a nézeteit idézi föl, akik átfogó képet alakítottak ki Európa lényegi jellemvonásairól és értékeiről. A kiemelkedő megközelítések sorában a lengyel katolikus Oscar Halecki, a szintén lengyel középkortörténész-politikus Bronisław Geremek, a brit történész Norman Davies mellett Bibó István és Szűcs Jenő teóriájáról is megemlékezik. A ,spengleri kérdést" föltevő fejezet az Európa-probléma nagy történetfilozófusai között, Spengler mellett, a Spengler-előd Giambattista Vicót és Nyikolaj Danyilevszkijt meg a Spengler-utód Arnold Toynbee-t tárgyalja. A világháború katasztrofális szellemi, politikai és gazdasági következményeit áttekintő fejezet hangsúlyosan kitér a háború megítélésében mutatkozó történészi konszenzusokra és nézetkülönbségekre. A német fejezet gerincét a német történelem különféle értelmezéseit nyújtó teóriák tárgyalása teszi ki, Friedrich Meineckétől és Thomas Manntól kezdve Lukács Györgyön és Norbert Eliason keresztül Ernst Noltéig és a Historikerstreitig. Az orosz fejezet, hasonlóképpen, az Oroszország-Európa viszonyt és az orosz identitást problematizáló reprezentatív teoretikusokat veszi sorra, a szlavofilektől az Eurázsia-eszme képviselőin keresztül a kortársi, a putyini politika szellemi hátterét megteremtő elméletírókig.

Gyurgyák kezén, bármiről beszéljen is éppen, előbb-utóbb minden eszmetörténetté válik. 
Az Európai Unió dilemmáit tárgyaló negyedik fejezet kedvéért ellenben új bekezdést kell nyitnunk. A könyvnek, akárhogy is, ez a szíve-közepe; ez magyarázza el, hogy Gyurgyák miért beszél ,alkonyról”, s hogy az „alkony” után aztán miért tesz mégis kérdőjelet. Ha valakit kizárólag a kötet politológiai mondanivalója érdekel, elég, ha ezzel a legterjedelmesebb fejezettel kezdi - meg akár: ezzel is fejezi be - az olvasást. Ebben is szerepel persze egy erős eszmetörténeti szál: a szerző fölidézi benne az unió gondolatának távolabbi és közelebbi elözményeit meg az unió létrejöttének alakulástörténetét. Az elözmények között Dantéig visszanyomozva, Kanton és Rousseau-n keresztül a Páneurópa-koncepciót megalkotó Richard Coudenhove-Kalergiig meg a Briand-tervet kidolgozó Aristide Briand-ig jut el; az alakulástörténet kiemelkedő alakjai között pedig Winston Churchillről, Jean Monnet-ról és Charles de Gaulle-ról emlékezik meg. A fejezet ábrázolásában az unió egyszerre tiszteletre méltóan sikeres múltú és elrémisztően zavaros - ha éppen nem reménytelen - jövőjü vállalkozás. Eddigi, hét évtizedes története, egyfelől, valódi sikertörténet. Sikerült létrehoznia a maga értékeire alapozott saját világát: megteremtette az emberi méltóság tiszteletére és a szabadságra alapozott demokratikus és jogállami berendezkedését; az együttmüködés nyomán javította az életföltételeket, és növelte az életszínvonalat; képes volt fönntartani a kontinens békéjének hosszú korszakát; szoros gazdasági-kulturális hálót hozott létre tagországai között; eredményesen tudta kezelni saját válságait; aktív szerepet játszott a világ válsággócainak kezelésében. Jövője, másfelől, valóban csupa kérdőjel. Tervezői eredetileg szerves processzusként képzelték el a kontinens államainak egységesülési folyamatát, kezdve a gazdasági, folytatva a védelmi, befejezve a politikai unióval, végcélként az Európai Egyesült Államokkal, amelynek aztán persze a kontinens valamennyi állama a tagjává válik majd. A csatlakozó államok önkéntesen korlátozzák saját szuverenitásukat, kapcsolatuk fokozatosan mélyül, körük pedig folyamatosan bővül. A rendszer önmagába épített lényege, afféle belső kód ez, ahogy Gyurgyák nevezi, Európa „monnet-i kódja”. Csakhogy a folyamat már az ötvenes évek közepén megakad, a védelmi unió gondolata megbukik, a politikai unió programja pedig nem valósul meg.

Az unió tagjai már nem nemzetállamok: szuverenitásuk jelentős részét elveszítették ugyanis. Maga az unió viszont nem föderáció mégsem: föderatív államhoz politikai-kulturális közösség kellene, annak kialakulásához meg összeurópai szolidaritásra volna szükség. Vissza nem lehet hát fordulni, előre meg nem járható az út. Mi, európai uniós polgárok, mintha csapdába estünk volna.

Gyurgyák amellett érvel, hogy a megoldás az európai konföderáció lehetne - de nem lehet az mégsem, az alapító atyák akarata, a „monnet-i kód” ezt meghiúsítja. A „nemzetek Európájának” sokat hangoztatott jelszava ráadásul duplafenekü fogalom: a föderáció ellenzőinek több csoportja is használhatja. Azok is emlegethetik - a szeriőz konzervatív euroszkeptikusok -, akik továbblépnének, valóban a konföderáció irányába fejlesztenék a társulást; és azok is megbújhatnak 
mögötte - a szuverén nemzetállam nacionalista hívei -, akik voltaképp inkább visszafordulnának, a régi nemzetállam felé indulnának megint. A hagyományos baloldal-jobboldal tengely helyét új törésvonal látszik elfoglalni: a szorosabb együttműködés, végső soron a föderális Európa hívei, a „rendszerpártok” állnak szemben a nemzetállami szuverenitáshoz ragaszkodó vagy éppen azt visszaszerezni igyekvő „rendszerellenes pártokkal”.

Gyurgyák a maga értékeiben bizonyos ugyan, a jövő ügyében bizonytalan. Miután hatalmas anyagát elénk tárta, voltaképp tanácstalanságának ad hangot: kétségek között hagyja olvasóját. Aki hát bizonyosságokra vágyik, ne próbálkozzon a könyvével. Olvasója bizonyosságot nem nyer: a tudása lesz mélyebb, és reflektálni lesz képes a maga mélyebb, de bizonyosságot nem ígérö tudására.

Hatalmas anyagot tár elénk, mondjuk újra, zárógondolatként. Gyurgyák, eddig is tudtuk róla, leginkább könyvtárakban szeret időzni. Említett korábbi, magyar tárgyú könyveit a nemzeti könyvtár 326-os számú olvasóhelyén írta. Aki nem ismerné, az irodalomtudományi olvasóteremnek ez az asztala talán az egész könyvtár legkellemesebb kutatóhelyeinek egyike: a megfáradt és könyvéből éppen fölpillantó olvasó a Naphegy ívének látványában pihentetheti meg a szemét. Mostani, európai tárgyú könyvének anyagát tengerentúli meg európai könyvtárakban gyüjtötte: az előszóban különféle oxfordi, berlini, bécsi és moszkvai könyvtárakról emlékszik meg szeretettel. Azokról a kutatóhelyekröl a Naphegyet nem láthatta ugyan, az olvasásban viszont, úgy tünik, nemigen zavarta senki. A könyvében megmozgatott lenyügöző irodalom mindenesetre ezt bizonyítja.

(Gyurgyák János: Európa alkonya? Utak és tévutak az európai történelemben és politikában. Budapest: Osiris, 2018)

Perecz László filozófiatörténész 